Article

\title{
Economic Transition, Technology Change, and Energy Consumption in China: A Provincial-Level Analysis
}

\author{
Xu Liu ${ }^{1} \mathbb{D}$, Jiang Lin ${ }^{1,2, *}$, Junfeng Hu ${ }^{1,3, *}$, Hongyou Lu ${ }^{1}$ and Jiaru Cai ${ }^{2}$ \\ 1 International Energy Analysis Deparment, Energy Analysis and Environmental Impacts Division, \\ Lawrence Berkeley National Laboratory, Berkeley, CA 94720, USA \\ 2 University of California-Berkeley, Berkeley, CA 94720, USA \\ 3 Beijing Key Laboratory of New Energy and Low-carbon Development, Economics and Management School, \\ North China Electric Power University, Beijing 102206, China \\ * Correspondence: j_lin@lbl.gov (J.L.); hjf@ncepu.edu.cn (J.H.)
}

Received: 26 April 2019; Accepted: 23 June 2019; Published: 4 July 2019

check for updates

\begin{abstract}
This paper conducts panel analysis to evaluate the effects of a structural economic shift from the industrial to the tertiary sector, a reduction in industrial overcapacity, and improvements in energy efficiency on energy consumption using data for 30 Chinese provinces from 1995 to 2015. We find that, at the national level, the structural shift to the tertiary sector, the reduction in cement and steel production, and the increase in energy efficiency in the industrial sector all have statistically significantly negative effects. We also divide the sample into three geographic and economic regions to evaluate regional differences. We find that the gross domestic product (GDP) share of the tertiary sector shows its greatest impact on reducing energy consumption in the eastern region, a decline in heavy industry production would reduce energy demand more in the central region, and improvement in industrial electricity efficiency would also help reduce energy consumption the most in eastern China. We also forecast energy consumption in China will reach 4.8-4.9 billion tonnes of coal equivalent (tce) in 2020 and further grow to $5.0-5.4$ billion tce in 2030 .
\end{abstract}

Keywords: economic transition; energy consumption; China; technology change

\section{Introduction}

China's economy has grown on average more than $10 \%$ per year for the past 30 years. In the midst of this rapid economic growth, it became the world's largest energy user and largest emitter of carbon dioxide $\left(\mathrm{CO}_{2}\right)$, accounting for $23 \%$ of the world's energy use and $28 \%$ of the world's energy-related $\mathrm{CO}_{2}$ emissions in 2016. In 2015, China committed to the Paris Agreement, pledging to peak its energy-related $\mathrm{CO}_{2}$ emissions by 2030, and earlier if possible. In addition, China aims to increase the percentage of non-fossil fuels (renewables, nuclear, and hydro) used in its total energy consumption to about $20 \%$ by 2030 (National Development and Reform Commission (NDRC), 2016) [1].

As illustrated by recent economic growth statistics and energy consumption data, from 2011 to 2015 China's economy slowed to an average growth rate of 7.4\%. In 2013, China consumed 2810 million tonnes of coal equivalent (Mtce). Coal use in 2014 declined to 2793 Mtce and declined further to 2752 Mtce in 2015. The annual average growth rate of China's primary energy consumption also decreased, from 9\% during the period 1980 to 2013, to 1\% from 2014 to 2016. In addition, China's economy is undergoing a structural shift from one based on industries to one that emphasizes tertiary (service) industries. During the past decade, the rate of growth of industries has slowed, and the overcapacity in key industrial sectors has started to decline. By 2016 tertiary industries (such as finance, hotels and catering, wholesale and retail, software companies, communications, education, and culture) 
represented about $52 \%$ of the national gross domestic product (GDP) (National Bureau of Statistics (NBS), 2018) [2].

China's current economic transition presents many unknowns and difficulties, however at the same time, slowing down coal and energy use could also alleviate China's environmental and climate challenges, including meeting ambitious goals for improving air quality and reducing $\mathrm{CO}_{2}$ emissions. Better understanding the key drivers of China's energy consumption at the national and regional level, especially under the condition of economic transition, can improve forecasts of energy demand and help with evaluating policies that may be able to modify trends in energy consumption.

This analysis considers the impacts of three key aspects of current transition on energy consumption, i.e., economic growth, structural changes illustrated by the share of the tertiary sector and heavy industry production, and technology improvement indicated by industrial electricity efficiency. More specifically, this analysis examines the relationships among energy consumption, gross domestic product (GDP), economic structure, overcapacity in heavy industries, population, electricity price, and industrial energy intensity in China. By examining provincial data from 1995 to 2015, the analysis captures inherent gains in energy productivity during the country's ongoing economic transition, from both a cross-sectional and a time-series perspective. This analysis augments the existing literature by capturing the ways in which energy consumption is affected by an economic transition that involves a structural shift to the tertiary sector, a reduction in overcapacity in key heavy industries, and increases in electricity efficiency in the industrial sector.

\section{Literature Review}

Multiple studies have found a statistically significant relationship between energy consumption and economic growth in China. Using provincial panel data from 1995 to 2008, Zhang and Xu [3] identified a causal relationship between China's economic growth and increased energy consumption at both the national and regional levels. Using data from 1980 to 2014 on China's GDP per capita and total energy consumption, Rathnayaka et al. [4] found a bidirectional causal relationship between energy consumption and economic growth in the long term. Zhang and Cheng [5] applied a multivariate model of economic growth, energy use, carbon emissions, and capital and urban population and suggested a unidirectional Granger causality from GDP to energy consumption and a unidirectional Granger causality running from energy consumption to carbon emissions in the long run. In addition, Yuan et al. [6] found that long-run cointegration exists among output, labor, capital, and energy use in China, at the aggregated level and also at the disaggregated levels as coal, oil, and electricity consumption. Studies using the IPAT model (IPAT is an equation that expresses the idea that environmental impact (I) is the product of three factors: population (P), affluence (A) and technology (T). $\mathrm{P}=$ population and refers to the total number of people.) have also found that China's economic growth has been, and will continue to be before 2020 [7], due to the impact of industrialization and largely dependent on massive energy consumption [8].

Recent research on China has examined specific sublevel indicators of energy consumption (such as electricity consumption, the quantity of secondary industry, and technology improvements) and economic growth (such as rising income or changing income distributions). Auffhammer and Wolfram [9] used the relationship between income and the adoption of energy-consuming durables as a proxy for electricity consumption. Using provincial data from 1998 to 2009, the study identified an S-shaped relationship between household income and appliance acquisitions in China. Zhang et al. [10] provide a comprehensive review of literature on the relationship between China's electricity consumption and economic growth from three dimensions (time, region, and industry), confirming the interaction among those variables. Zhang et al. [11] pointed out the important role of secondary industry in energy consumption per capita, noting that the relationships between energy consumption per capita and GDP per capita differ among provinces. Fang et al. [12] examined the effect of changes in energy structure, improvements in energy technology, and economic growth on 
energy intensity in China. The study found that adjustments to economic structure can lower energy intensity without compromising economic growth.

Other studies have focused on the difference between urban and rural patterns in energy use and economic growth in China. Using provincial panel data from 1995 to 2010, Zhang and Lin [13] analyzed the effect of urbanization on energy consumption and $\mathrm{CO}_{2}$ emissions at both national and regional levels. They found that urbanization had a positive effect on energy consumption and $\mathrm{CO}_{2}$ emissions. This effect differed among regions, however, with urbanization increasing energy consumption and $\mathrm{CO}_{2}$ emissions the most in China's central region, and less so in the eastern and western regions. Hao et al. [14] identified a bilateral relationship between GDP and energy consumption in rural areas. Yang et al. [15] investigated the effect of urbanization on economic growth and energy consumption at the prefecture level. Their results indicated that urbanization had a positive and significant impact on economic growth from 2000 to 2010. A summary of these studies, including their main conclusions, variables, and methodologies used, is presented in Table 1. 
Table 1. Summary of Literature Review: Conclusions, Variables, and Methodologies.

\begin{tabular}{|c|c|c|c|}
\hline Authors & Main Conclusions & Variables & Methodologies \\
\hline Yuan et al. [6] & $\begin{array}{l}\text { Long-run cointegration among output, labor, capital and } \\
\text { energy use in China at both aggregated and disaggregated } \\
\text { levels (coal, oil, and electricity consumption) exists. }\end{array}$ & Capital, labor, energy & $\begin{array}{l}\text { Neo-classical aggregate production model } \\
\text { Johansen cointegration technique; Granger } \\
\text { causality test }\end{array}$ \\
\hline Song et al. [8] & $\begin{array}{l}\text { Found that China's high-speed economic growth is still } \\
\text { largely dependent on massive energy consumption. }\end{array}$ & $\begin{array}{l}\text { Population, annual added value of GDP, annual } \\
\text { decline rates of energy consumption. }\end{array}$ & Expanded IPAT equation \\
\hline Wang et al. [16] & $\begin{array}{l}\text { Showed that primary energy demands and } \mathrm{CO}_{2} \\
\text { emissions will grow rapidly before } 2020 \text { due to impact of } \\
\text { industrialization. }\end{array}$ & $\begin{array}{l}\text { Population, GDP per capita, total energy demand, } \\
\text { energy intensity, } \mathrm{CO}_{2} \text { emissions, carbon emission } \\
\text { intensity }\end{array}$ & IPAT model \\
\hline Zhang and Cheng [5] & $\begin{array}{l}\text { Suggested a unidirectional Granger causality from GDP } \\
\text { to energy consumption and a unidirectional Granger } \\
\text { causality running from energy consumption to carbon } \\
\text { emissions in the long run. }\end{array}$ & $\begin{array}{l}\text { Real GDP, gross fixed capital formation, energy } \\
\text { consumption, } \mathrm{CO}_{2} \text { emissions, urban population }\end{array}$ & $\begin{array}{c}\text { Augmented vector autoregression approach; unit } \\
\text { root tests }\end{array}$ \\
\hline Zhang and Lin [13] & $\begin{array}{l}\text { Pointed out that urbanization had a positive effect on } \\
\text { energy consumption and } \mathrm{CO}_{2} \text { emissions. }\end{array}$ & $\begin{array}{l}\text { Population, GDP per capita, the share of industry } \\
\text { sector in GDP, and the share of service sector in GDP }\end{array}$ & $\begin{array}{l}\text { Stochastic Impacts by Regression on Population, } \\
\text { Affluence, and Technology (STIRPAT) }\end{array}$ \\
\hline Zhang and $\mathrm{Xu}[3]$ & $\begin{array}{l}\text { Identified a causal relationship between China's economic } \\
\text { growth and increased energy consumption at both the } \\
\text { national and regional levels. }\end{array}$ & $\begin{array}{c}\text { Total energy use, energy use by sector, GDP per } \\
\text { capita, and sectoral value-added per capita, price } \\
\text { index of total energy use, and price index of sectoral } \\
\text { energy use }\end{array}$ & $\begin{array}{l}\text { Panel methods to test for unit roots, cointegration } \\
\text { relations and Granger causality. }\end{array}$ \\
\hline Zhang et al. [10] & $\begin{array}{l}\text { Review of literature on the relationship between China's } \\
\text { electricity consumption and economic growth from three } \\
\text { dimensions (time, region, and industry), confirming the } \\
\text { interaction among those variables. }\end{array}$ & Electricity consumption, GDP & $\begin{array}{c}\text { Reviewed key modeling approaches: } \\
\text { autoregressive distributed lag (ARDL) model; } \\
\text { vector autoregressive model (VAR), error } \\
\text { correction model (ECM), ordinary least squares } \\
\text { method (OLS), dynamic ordinary least squares } \\
\text { (DOLS) }\end{array}$ \\
\hline $\begin{array}{l}\text { Auffhammer and } \\
\text { Wolfram [9] }\end{array}$ & $\begin{array}{l}\text { Identified an S-shaped relationship between household } \\
\text { income and appliance acquisitions in China. }\end{array}$ & $\begin{array}{l}\text { Income and adoption of energy-consuming } \\
\text { durables (proxy for electricity consumption) }\end{array}$ & Logistic diffusion curve models \\
\hline Yang et al. [15] & $\begin{array}{l}\text { Indicated that urbanization had a positive and significant } \\
\text { impact on economic growth from } 2000 \text { to } 2010 \text {. }\end{array}$ & $\begin{array}{l}\text { GDP per capita, electricity consumption per capita, } \\
\text { urbanization rate, capital formation per capita }\end{array}$ & $\begin{array}{l}\text { Stochastic Impacts by Regression on Population, } \\
\text { Affluence, and Technology (STIRPAT) }\end{array}$ \\
\hline Fang et al. [12] & $\begin{array}{l}\text { Found adjustments to economic structure can lower } \\
\text { energy intensity without compromising economic growth. }\end{array}$ & $\begin{array}{l}\text { Carbon emissions, economic growth, new energy } \\
\text { (hydro, wind and nuclear) }\end{array}$ & $\begin{array}{c}\text { Developed a 4D Energy Saving and Emission } \\
\text { Reduction (ESER) system }\end{array}$ \\
\hline Hao et al. [14] & $\begin{array}{l}\text { Identified a bilateral relationship between GDP and } \\
\text { energy consumption in rural areas }\end{array}$ & $\begin{array}{l}\text { Rural GDP, rural investment, and rural energy } \\
\text { consumption }\end{array}$ & $\begin{array}{l}\text { Vector autoregressive model (VAR), vector error } \\
\text { correction model (VECM), and fully modified } \\
\text { ordinary least squares (FMOLS) }\end{array}$ \\
\hline Rathnayaka et al. [4] & $\begin{array}{l}\text { Found a bidirectional causal relationship between energy } \\
\text { consumption and economic growth in the long term. }\end{array}$ & $\begin{array}{l}\text { Real GDP per capita, total energy consumption, } \\
\text { total population }\end{array}$ & $\begin{array}{l}\text { Vector error correction model; unit root and } \\
\text { cointegration test; Granger causality test }\end{array}$ \\
\hline Zhang et al. [11] & $\begin{array}{c}\text { Pointed out that relationships between energy } \\
\text { consumption per capita and GDP per capita differ among } \\
\text { provinces. }\end{array}$ & $\begin{array}{l}\text { Real GDP per capita, secondary industry } \\
\text { value-added to GDP, energy consumption per capita }\end{array}$ & Autoregressive distributed lag (ARDL) model \\
\hline
\end{tabular}




\section{Methods}

We estimated the effect of the elasticity of economic growth on energy consumption (that is, the amount energy consumption increases for every increase in unit of economic growth) based on the stochastic impacts by regression on population, affluence, and technology model $[13,15,17,18]$ :

$$
\mathrm{I}_{\mathrm{i}}=\mathrm{aP}_{\mathrm{i}} \mathrm{b}^{*} \mathrm{~A}_{\mathrm{i}}{ }^{\wedge} \mathrm{c}^{*} \mathrm{~T}_{\mathrm{i}}{ }^{\wedge} \mathrm{d}^{*} \varepsilon_{\mathrm{i}}
$$

Where, I denotes energy consumption, P population, A for affluence, and T for technology. We use GDP per capita to measure affluence, and GDP share of tertiary industry, crude steel production per capita, cement production per capita, and industrial electricity intensity to measure technology. So Equation (1) can be transformed to:

$$
\begin{gathered}
\bar{I}_{i t}=a *\left(\frac{A}{P}\right)_{i t}^{b} *\left(\frac{T}{P}\right)_{i t}^{c} * \varepsilon_{i t} \\
\operatorname{LnI}_{\mathrm{it}}=\mathrm{a}+\mathrm{bLnA}_{\mathrm{it}}+\mathrm{cLnT}_{\mathrm{it}}+\varepsilon_{\mathrm{it}}
\end{gathered}
$$

So, more specifically, in Equation (3):

$\mathrm{I}_{\mathrm{it}}$ is total energy consumption of province $\mathrm{i}$ in year $\mathrm{t}$;

$A_{i t}$ is GDP per capita of province $\mathrm{i}$ in year $\mathrm{t}$;

$\mathrm{T}_{i t}$ is the tertiary sector's value-added share of GDP, crude steel and cement production per capita, and industrial energy intensity of province I in year $\mathrm{t}$, and $\varepsilon_{i t}$ is an error term.

To avoid possible spurious regression effects caused by non-stationary panel data, we conducted panel unit root tests and panel cointegration tests (Wang, et al. 2011; Wang et al., 2014) [7,19]. A paper by Lee (2005) [20] is the first to describe using the panel cointegration test to identify the relationship between energy consumption and GDP. We first examined the stationarity of the panel data using panel unit root tests. We used four methods for panel unit root tests, i.e., Levin-Lin-Chu (LLC), Im-Pesaran-Shin (IPS), Fisher - ADF, and Fisher - PP [21-24]. Then, we conducted panel cointegration tests to examine the long-term relationship between energy consumption and the independent variables. If a cointegration relationship was found to exist, we conducted panel cointegration estimation using panel fully-modified ordinary least squares (FMOLS).

The ordinary least squares (OLS) method can be used instead if no cointegration relationship is found and the data are stationary. We first conducted Hausman tests and likelihood ratio tests by both cross-section and time dimensions to determine the use of a random-effects model or a fixed-effects model. After determining the model, we conducted panel data regression to examine the impacts of independent variables on energy consumption per capita. We estimated the function using fixed effects with Driscoll-Kraay standard errors, which are robust to disturbances that are heteroskedastic, autocorrelated, and cross-sectionally dependent [25].

We evaluated regional characteristics by examining three regions identified by geographic location and economic development: eastern (Beijing, Fujian, Guangdong, Hainan, Hebei, Liaoning, Jiangsu, Shandong, Shanghai, Tianjin, and Zhejiang), central (Anhui, Heilongjiang, Henan, Hubei, Hunan, Jilin, Jiangxi, and Shanxi), and western (Chongqing, Gansu, Guangxi, Guizhou, Inner Mongolia, Ningxia, Qinghai, Shanxi, Sichuan, Xinjiang, and Yunnan) (Figure 1) [3,13]. (Tibet is not included because of a lack of data.)

We compared the regional model using both panel cointegration and OLS regression as described above and conducted relevant tests as well. Then we used the panel cointegration model to forecast regional energy consumption in 2020 and 2030 and evaluated the effects of economic transition and technology change on energy consumption. 


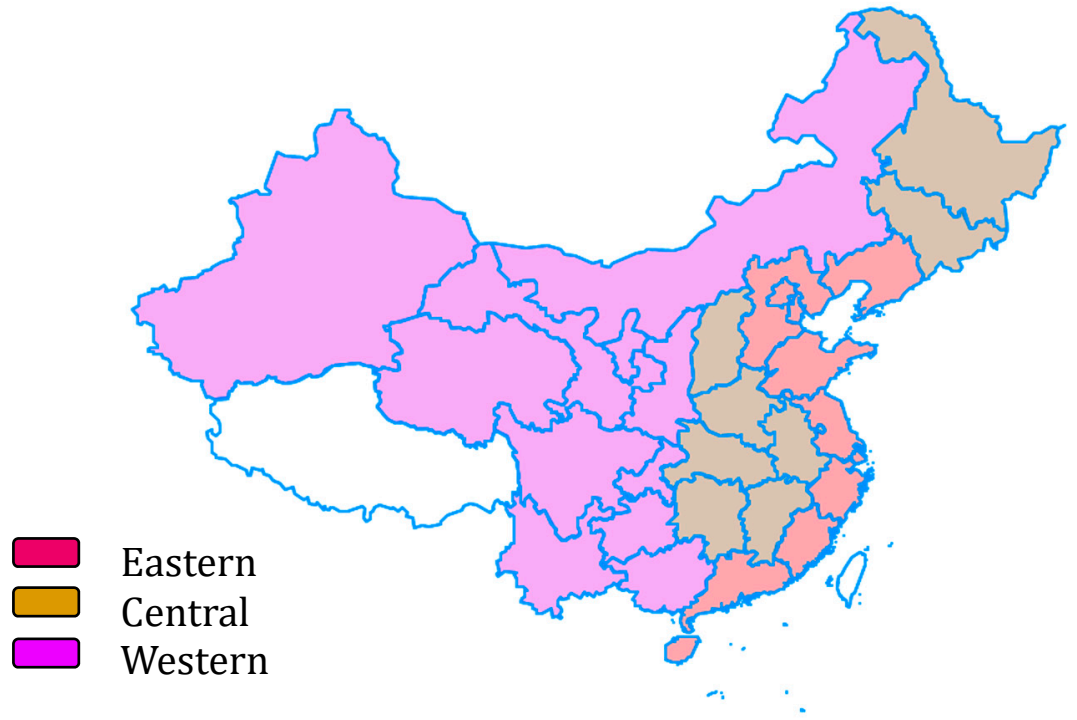

Figure 1. Regional breakdown in the study.

\section{Data}

Data from 1995 to 2015 were gathered for 30 provinces. Data on provincial GDP, population, cement and steel production, and share of the tertiary sector were obtained from China's NBS database and China Statistical Yearbooks [2,26]. GDPs were converted to 1995 yuan constant prices by using the price index from the NBS database. Total energy consumption and industrial electricity use at the provincial level were collected from the China Energy Statistical Yearbooks [27].

Electricity use per unit of industrial value added was used to measure industrial energy intensity. Provincial-level industrial values added for 1995 to 2015 were obtained from the NBS's Statistical Yearbooks. Industrial value added was adjusted to real value added using the 1995 price. Table 2 provides a summary of descriptive statistics of the model variables.

Table 2. Descriptive statistics of model variables.

\begin{tabular}{ccccccc}
\hline Variable & Observations & Units & Mean & Std. Dev. & Min & Max \\
\hline Provincial GDP per capita & 630 & 1995 yuan/capita & 20,551 & 17,370 & 2297 & 117,725 \\
Energy consumption per capita & 627 & kgce/capita & 2374 & 1466 & 419 & 8091 \\
Cement production per capita & 629 & kg/capita & 887 & 665 & 49 & 3205 \\
Steel production per capita & 621 & g/capita & 308,152 & 397,416 & 12 & $2,570,654$ \\
Industrial electricity intensity & 622 & $\mathrm{kWh} / 1995$ yuan & 0.28 & 0.22 & 0.08 & 1.32 \\
Tertiary sector share & 630 & $\%$ & $40 \%$ & $8 \%$ & $28 \%$ & $80 \%$ \\
\hline
\end{tabular}

Figure 2 shows energy consumption and GDP per capita in 1995 and 2015 in the three regions we have defined.

In 1995, GDP per capita in eastern, western, and central China was 9200, 3700, and 4500 yuan (1995 price) respectively, skyrocketing to 61,900,31,200, and 33,400 yuan respectively, in 2015. While GDP per capita increased almost seven-fold, energy consumption in eastern China had reached 3.68 tce/capita by 2015, almost 3 times the 1995 level (1.34 tce/capita). Energy consumption per capita in western China grew at the fastest rate, from 0.85 tce/capita in 1995 to 3.32 tce/capita in 2015. In central China, tce/capita increased from 1.05 in 1995 to 2.68 in 2015.

Figure 2 illustrates the changes in energy consumption, population, GDP per capita, steel production, cement production, industrial electricity intensity, and tertiary share in 2015 compared with 1995. 


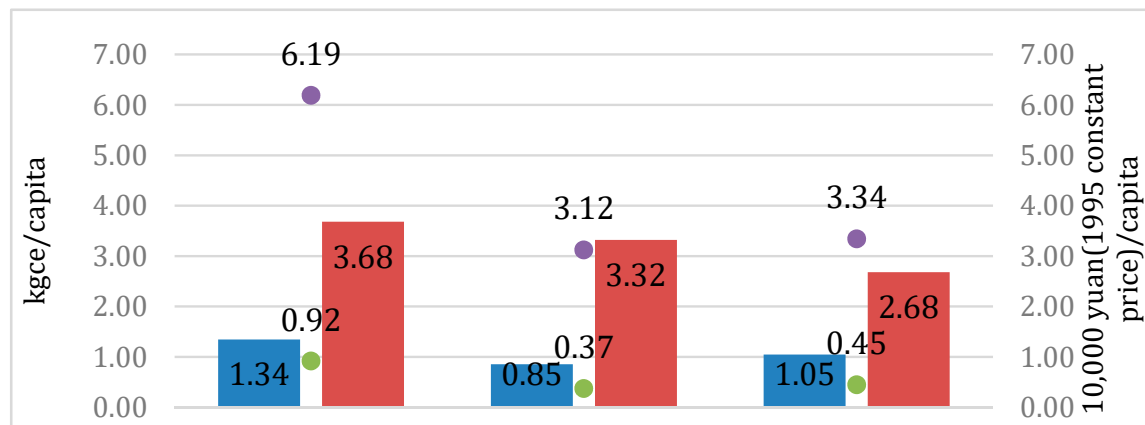

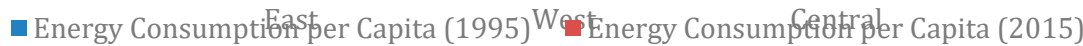
- GDP per Capita (1995) - GDP per Capita (2015)

Figure 2. Energy consumption and gross domestic product (GDP) per capita in 1995 and 2015 by region.

Figure 3 shows not only the rapid growth in GDP per capita and energy consumption in all regions (also evident in Figure 1), but also a significant increase in cement and steel production. By 2015, however, both cement and steel production generally decreased in all regions (except for steel production in the eastern region). The increase in energy consumption slowed from 2011 to 2015 compared with previous years.

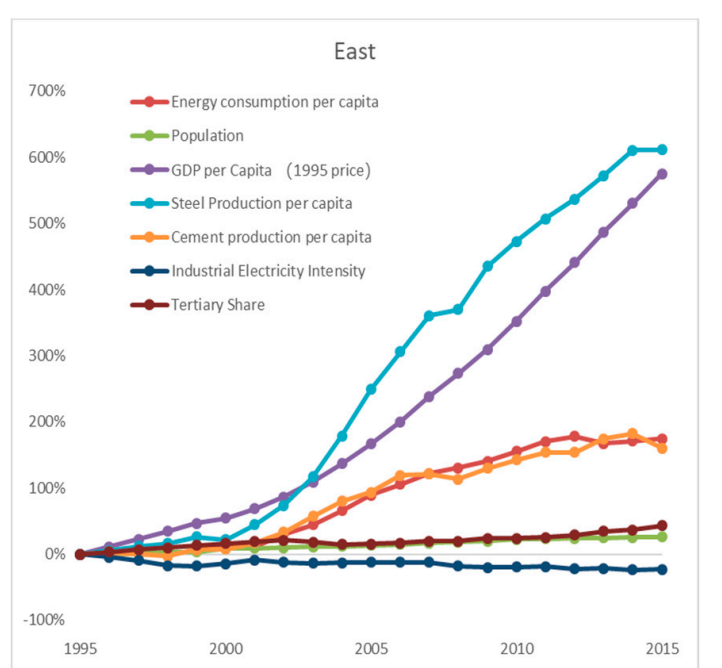

(a)

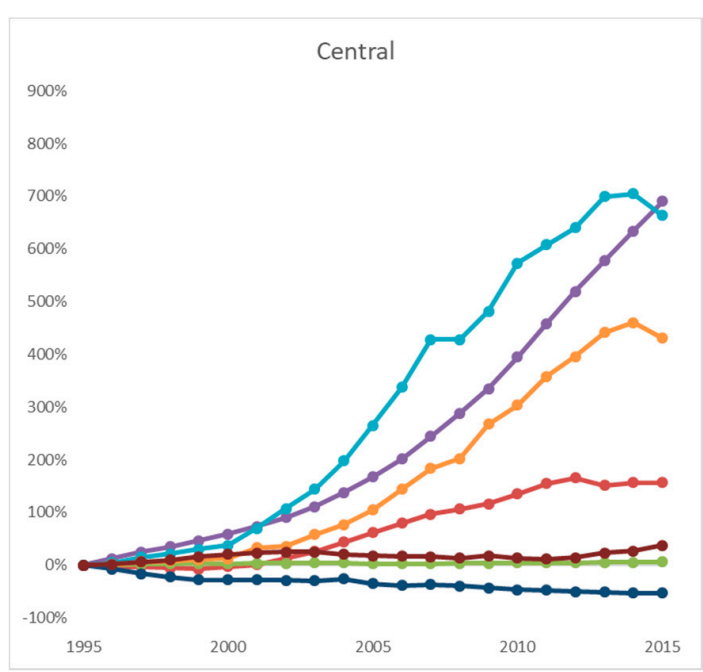

(b)

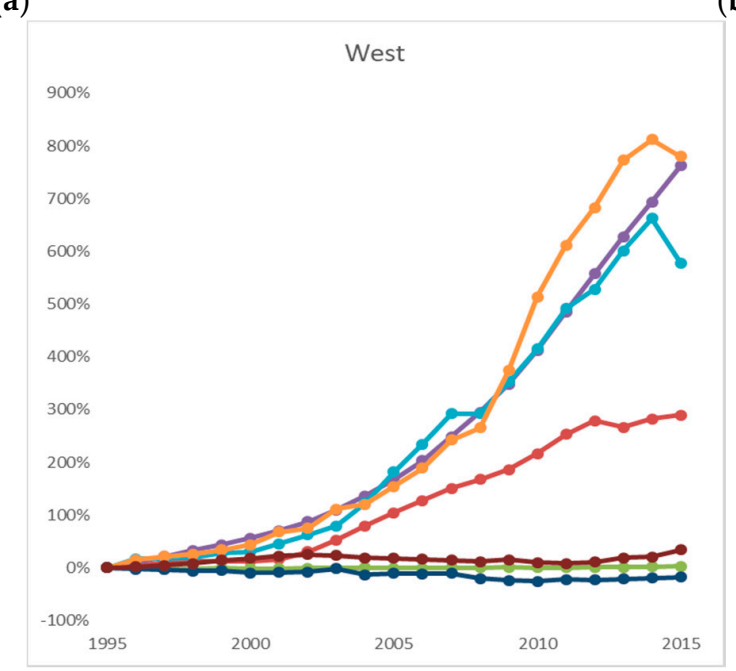

(c)

Figure 3. Trends of key variables from 1995 to 2015 by region. 
The share of tertiary industry in eastern China increased during the past decades, fluctuating in other regions from 1995 to 2010, after which it started to increase continuously. Central China's industrial electricity intensity experienced the most significant decrease, about 54\% from 1995 to 2015 . Industrial electricity intensity decreased more slowly in western China, with the 2015 level being about 18\% below that of the 1995 level. In eastern China, industrial electricity intensity decreased from 1995 to 1999-the 1999 level being 18\% below the 1995 level, but then bounced back and from 2000 to 2007 fluctuated at about 12\% below the 1995 level. Industrial electricity intensity decreased and fluctuated again from 2008 to 2015, when it reached 23\% below the 1995 level. The trends in industrial electricity intensity indicate that economic transitions occurred across the nation, involving a structural shift toward the tertiary sector, a slowdown or reduction in heavy industry production, and improvement in energy efficiency.

\section{Results}

Table 3 shows the panel unit root results for each variable using the whole sample and samples by region. The results show that not all variables in level form are statistically significant under all tests, but all variables in the first-order differencing form are statistically significant under all tests, except for the Central China sample. As a result, we can conclude that all variables are integrated of order one, i.e., I(1), for the whole China sample, the East China sample, and the West China sample, and we can perform a panel cointegration test for them. For central China, GDP per capita is non-stationary at the first difference order, so we cannot perform a panel cointegration test for the central China sample.

Table 3. Results of panel unit root tests.

\begin{tabular}{|c|c|c|c|c|c|}
\hline \multirow{2}{*}{ Variables } & & \multicolumn{4}{|c|}{ Test Methods } \\
\hline & & LLC & \multirow[t]{2}{*}{ IPS } & \multirow[t]{2}{*}{ ADF-Fisher } & \multirow[t]{2}{*}{ PP-Fisher } \\
\hline \multicolumn{3}{|c|}{ The Whole China } & & & \\
\hline \multirow{2}{*}{ Energy consumption per capita } & Level & $-3.84^{* * *}$ & 0.67 & 49.49 & 33.68 \\
\hline & 1st difference & $-9.25^{* * *}$ & $-5.65^{* * *}$ & $130.76^{* * *}$ & $171.28^{* * *}$ \\
\hline \multirow{2}{*}{ GDP per capita } & Level & $-2.87 * * *$ & $-5.78^{* * *}$ & $137.84^{* * *}$ & 66.10 \\
\hline & 1st difference & $-3.56^{* * *}$ & $-4.89 * * *$ & $117.95^{* * *}$ & $92.70 * * *$ \\
\hline \multirow{2}{*}{ Tertiary share } & Level & $-2.44^{* * *}$ & -0.02 & $160.12 * * *$ & $295.65^{* * *}$ \\
\hline & 1st difference & $-7.47^{* * *}$ & $-6.84^{* * *}$ & $91.66^{* * *}$ & $109.57^{* * *}$ \\
\hline \multirow{2}{*}{ Steel production per capita } & Level & $-4.81^{* * *}$ & 2.12 & $312.07^{* * *}$ & $317.97^{* * *}$ \\
\hline & 1st difference & $-11.46^{* * *}$ & $-6.32^{* * *}$ & $162.08^{* * *}$ & $236.58 * * *$ \\
\hline \multirow{2}{*}{ Cement production per capita } & Level & $-5.66^{* * *}$ & $-1.51 *$ & $119.01^{* * *}$ & $100.80^{* * *}$ \\
\hline & 1st difference & $-11.88^{* * *}$ & $-7.67^{* * *}$ & $179.55^{* * *}$ & $220.35^{* * *}$ \\
\hline \multirow{2}{*}{ Industrial electricity intensity } & Level & 0.00 & -0.36 & 70.35 & $74.87 *$ \\
\hline & 1st difference & $-17.97^{* * *}$ & $-13.81^{* * *}$ & $265.48^{* * *}$ & $356.15^{* * *}$ \\
\hline \multicolumn{6}{|c|}{ The East China Sample } \\
\hline \multirow{2}{*}{ Energy consumption per capita } & Level & $-2.80 * * *$ & 0.84 & 12.99 & 7.87 \\
\hline & 1st difference & $-7.32 * * *$ & $-4.95^{* * *}$ & $62.84^{* * *}$ & $60.38^{* * *}$ \\
\hline \multirow{2}{*}{ GDP per capita } & Level & $-3.28^{* * *}$ & $-2.96^{* * *}$ & $47.68^{* * *}$ & 13.79 \\
\hline & 1st difference & $-2.69 * * *$ & $-4.01 * * *$ & $53.45^{* * *}$ & $36.91 * *$ \\
\hline \multirow{2}{*}{ Tertiary share } & Level & $-7.00 * * *$ & 0.71 & $95.06^{* * *}$ & $281.48^{* * *}$ \\
\hline & 1st difference & $-6.80 * * *$ & $-4.57^{* * *}$ & $59.95^{* * *}$ & $64.26^{* * *}$ \\
\hline \multirow{2}{*}{ Steel production per capita } & Level & $-3.21 * * *$ & 1.27 & $78.64^{* * *}$ & $85.22 * * *$ \\
\hline & 1st difference & $-8.11^{* * *}$ & $-4.42 * * *$ & $62.11^{* * *}$ & $99.44^{* * *}$ \\
\hline \multirow{2}{*}{ Cement production per capita } & Level & $-1.78^{* *}$ & 2.18 & $30.97 *$ & 26.43 \\
\hline & 1st difference & $-6.55^{* * *}$ & $-4.52 * * *$ & $59.78^{* * *}$ & $90.52 * * *$ \\
\hline \multirow{2}{*}{ Industrial electricity intensity } & Level & $-1.70 * *$ & $-1.55^{*}$ & $31.70 *$ & 29.58 \\
\hline & 1st difference & $-10.37^{* * *}$ & $-9.37^{* * *}$ & $109.06^{* * *}$ & $135.33^{* * *}$ \\
\hline
\end{tabular}


Table 3. Cont.

\begin{tabular}{|c|c|c|c|c|c|}
\hline \multirow{2}{*}{ Variables } & & \multicolumn{4}{|c|}{ Test Methods } \\
\hline & & LLC & IPS & ADF-Fishe & PP-Fisher \\
\hline \multicolumn{6}{|c|}{ The West China Sample } \\
\hline \multirow{2}{*}{ Energy consumption per capita } & Level & -0.60 & $-1.32 *$ & 26.44 & 14.09 \\
\hline & 1st difference & $-3.41^{* * *}$ & $-5.10 * * *$ & $65.51 * * *$ & $72.69^{* * *}$ \\
\hline \multirow{2}{*}{ GDP per capita } & Level & $-5.02 * * *$ & $-4.19 * * *$ & $56.80^{* * *}$ & $52.87^{* * *}$ \\
\hline & 1st difference & $-2.93 * * *$ & $-2.93^{* * *}$ & $44.70^{* * *}$ & $39.26 * *$ \\
\hline \multirow{2}{*}{ Tertiary share } & Level & $-3.65^{* * *}$ & $-1.39 *$ & $34.55^{* *}$ & $46.80^{* * *}$ \\
\hline & 1st difference & $-4.24 * * *$ & $-3.65^{* * *}$ & $52.92 * * *$ & $47.55^{* * *}$ \\
\hline \multirow{2}{*}{ Steel production per capita } & Level & $-8.99 * * *$ & 1.00 & $103.40^{* * *}$ & $118.12^{* * *}$ \\
\hline & 1st difference & $-4.11^{* * *}$ & $-3.73 * * *$ & $62.67 * * *$ & $95.53 * * *$ \\
\hline \multirow{2}{*}{ Cement production per capita } & Level & $-4.78^{* * *}$ & $-3.75^{* * *}$ & $53.90 * * *$ & $41.32 * * *$ \\
\hline & 1st difference & $-7.29 * * *$ & $-5.26^{* * *}$ & $74.45^{* * *}$ & $81.11^{* * *}$ \\
\hline \multirow{2}{*}{ Industrial electricity intensity } & Level & 0.55 & 1.05 & 22.14 & 30.09 \\
\hline & 1st difference & $-12.57^{* * *}$ & $-8.22 * * *$ & $95.34^{* * *}$ & $132.06^{* * *}$ \\
\hline \multicolumn{6}{|c|}{ The Central China Sample } \\
\hline \multirow{3}{*}{ Energy consumption per capita } & Level & $-3.08^{* * *}$ & 0.21 & 20.23 & 13.46 \\
\hline & 1st difference & $-5.30 * * *$ & $-2.52 * * *$ & $40.24^{* * *}$ & $38.20 * * *$ \\
\hline & Level & $-3.84^{* * *}$ & $-2.81^{* * *}$ & $33.35^{* * *}$ & 8.74 \\
\hline \multirow[t]{2}{*}{ GDP per capita } & 1st difference & $-1.76^{* *}$ & -1.28 & 19.79 & 16.53 \\
\hline & 2nd differenct & $-11.86^{* * *}$ & $-7.96^{* * *}$ & $78.56^{* * *}$ & $86.70 * * *$ \\
\hline \multirow{2}{*}{ Tertiary share } & Level & $-3.46^{* * *}$ & 0.16 & $30.51 * *$ & $30.34 * *$ \\
\hline & 1st difference & $-3.62 * * *$ & $-3.60 * * *$ & $39.67^{* * *}$ & $37.95^{* * *}$ \\
\hline \multirow{2}{*}{ Steel production per capita } & Level & $-11.01^{* * *}$ & $-8.92 * * *$ & $88.81^{* * *}$ & $152.15^{* * *}$ \\
\hline & 1st difference & $-3.26^{* * *}$ & 0.06 & $130.03^{* * *}$ & 114.64 \\
\hline \multirow{2}{*}{ Cement production per capita } & Level & $-7.40^{* * *}$ & $-2.67^{* * *}$ & $37.29 * * *$ & $41.60^{* * *}$ \\
\hline & 1st difference & $-5.34^{* * *}$ & -0.83 & $45.30^{* * *}$ & $33.04^{* * *}$ \\
\hline \multirow{2}{*}{ Industrial electricity intensity } & Level & $-6.77^{* * *}$ & $-3.38^{* * *}$ & $45.32 * * *$ & $48.72 * * *$ \\
\hline & 1st difference & $-1.52 *$ & -0.10 & 16.50 & 17.59 \\
\hline
\end{tabular}

Note: 1. Automatic lag length selection based on SIC; 2 . Newey-West automatic bandwidth selection and Quadratic Spectral kernel; 3 . Individual intercept and trend selection based on significance; $4 .{ }^{*}, * *, * * *$ indicate significance at the 10 percent, 5 percent, and 1 percent level, respectively.

The results of panel cointegration test for whole China, East China, and West China are shown in Table 4. The Panel PP-statistic, Panel ADF-Statistic, Group PP-Statistic, Group ADF-Statistic, and Kao tests all statistically significantly reject the null of no cointegration. As a result, we believe there exist a long-run relationship between the variables.

Table 4. Results of panel cointegration tests.

\begin{tabular}{ccccc}
\hline \multicolumn{2}{c}{ Test Methods } & Whole China & East China & West China \\
\hline & Panel v-Statistic & -1.77 & -0.97 & -1.43 \\
& Panel rho-Statistic & 4.34 & 1.83 & $3.48^{* *}$ \\
& Panel PP-Statistic & $-9.58^{* * *}$ & $-9.39^{* * *}$ & $-5.65^{* * *}$ \\
Pedroni & Panel ADF-Statistic & $-8.04^{* * *}$ & $-7.81^{* * *}$ & $-3.70^{* * *}$ \\
& Group rho-Statistic & 6.31 & 3.40 & $4.47^{* * *}$ \\
& Group PP-Statistic & $-24.98^{* * *}$ & $-8.54^{* * *}$ & $25.76^{* * *}$ \\
& Group ADF-Statistic & $-9.94^{* * *}$ & $-6.52^{* * *}$ & $-4.98^{* * *}$ \\
\hline \multicolumn{2}{c}{ Kao (Engle-Granger based) } & $-6.58^{* * *}$ & $4.59^{* * *}$ & $-4.59^{* * *}$ \\
\hline
\end{tabular}

Note: ${ }^{*}, * *{ }^{* * *}$ indicate significance at the 10 percent, 5 percent, and 1 percent level, respectively.

For central China, we conducted the Hausman test and likelihood ratio test and the results show that the fixed-effects model should be used (Table 5). So, we used the panel cross-section fixed-effects model for the central China sample. Table 6 shows panel integration estimations for the whole China, 
East China, and West China, as well as panel random-effects regression estimation for Central China. Table 7 provides the results of testing if multicollinearitry exists. The results show that all variables had variance inflation factors (VIFs) lower than 10, except for GDP per capita and cement production per capita in the West China sample, indicating no multicollinearitry for the whole China sample, East China and West China samples. For the West China sample, after excluding cement per capita, all VIFs are below 10.

Table 5. Results of the Hausman test and the likelihood ratio test.

\begin{tabular}{cccc}
\hline Region & Hausman Test & Likelihood Ratio & Model Type \\
\hline central & $257.55^{* * *}$ & $76.81^{* * *}$ & fixed \\
\hline
\end{tabular}

Note: ${ }^{* * *, * * *}$ indicate significance at the 10 percent, 5 percent, and 1 percent level, respectively.

Table 6. Estimation results.

\begin{tabular}{|c|c|c|c|c|}
\hline $\begin{array}{c}\text { Dependent Variable } \\
\text { Energy Consumption } \\
\text { Per Capita }\end{array}$ & & & & \\
\hline Independent Variables & Whole China & East China & West China & Central China \\
\hline \multirow[t]{2}{*}{$\begin{array}{c}\text { Provincial GDP per } \\
\text { capita }\end{array}$} & $0.74^{* * *}$ & $0.83^{* * *}$ & $0.85^{* * *}$ & $0.51^{* * *}$ \\
\hline & $(0.012)$ & $(0.016)$ & $(0.018)$ & $(0.056)$ \\
\hline \multirow[t]{2}{*}{ Tertiary share } & $-0.84^{* * *}$ & $-1.23^{* * *}$ & $-0.89^{* * *}$ & $-0.61^{* * *}$ \\
\hline & $(0.032)$ & $(0.076)$ & $(0.068)$ & $(0.077)$ \\
\hline \multirow[t]{2}{*}{$\begin{array}{l}\text { Steel production per } \\
\text { capital }\end{array}$} & $0.03^{* * *}$ & $0.01^{* * *}$ & -0.01 & $0.14^{* * *}$ \\
\hline & $(0.003)$ & $(0.003)$ & $(0.014)$ & $(0.027)$ \\
\hline \multirow[t]{2}{*}{$\begin{array}{l}\text { Cement production per } \\
\text { capita }\end{array}$} & $0.07^{* * *}$ & $0.05^{* * *}$ & $\begin{array}{l}\text { Cement production per capita } \\
\text { is excluded in the western } \\
\text { sample analysis because VIFs } \\
\text { test results show that without } \\
\text { cement production per capita, } \\
\text { all independent variables have } \\
\text { VIFs lower than } 10 \text { (Table } 7 \text { ). }\end{array}$ & $0.16^{* * *}$ \\
\hline & $(0.010)$ & $(0.013)$ & & $(0.045)$ \\
\hline \multirow[t]{2}{*}{$\begin{array}{l}\text { Industrial electricity } \\
\text { intensity }\end{array}$} & $0.46^{* * *}$ & $0.63^{* * *}$ & $0.41^{* * *}$ & $0.50^{* * *}$ \\
\hline & $(0.014)$ & $(0.028)$ & $(0.026)$ & $(0.048)$ \\
\hline \multirow[t]{2}{*}{ Constant } & & & & -0.03 \\
\hline & & & & $(0.182)$ \\
\hline Observations & 579 & 211 & 208 & 168 \\
\hline R-squared & 0.979212 & 0.983223 & 0.976287 & 0.981905 \\
\hline Number of provinces & 30 & 11 & 11 & 8 \\
\hline
\end{tabular}

Note: Standard errors are reported in parentheses. Use of ${ }^{*}, * * * * *$ indicates significance at the $10 \%, 5 \%$, and $1 \%$ level, respectively. 
Table 7. Results of the variance inflation factor (VIF) test.

\begin{tabular}{lccccc}
\hline \multicolumn{1}{c}{ Variable } & Whole & East & Central & $\begin{array}{c}\text { West (All } \\
\text { Variables) }\end{array}$ & $\begin{array}{c}\text { West (Excluding Cement } \\
\text { Production Per Capita) }\end{array}$ \\
\hline LGDPCAPITA & 8.96 & 5.58 & 5.45 & 43.56 & 4.04 \\
\hline LTERTIARYSHARE & 1.39 & 3.45 & 1.32 & 1.16 & 1.08 \\
\hline LSTEELCAPITA & 1.95 & 2.69 & 7.68 & 3.15 & 3.91 \\
\hline LCEMENTCAPITA & 8.72 & 2.43 & 7.81 & 37.48 & Excluded \\
\hline LINDUSTRIALEI & 1.43 & 2.76 & 3.28 & 1.19 & 1.11 \\
\hline
\end{tabular}

The whole China results show that provincial GDP per capita, cement and steel production per capita, and industrial energy intensity have statistically significantly positive impacts on energy consumption per capita, while tertiary share of GDP has a significant negative impact, all at the $1 \%$ level. The magnitude of impacts of each independent variable are shown from the coefficients of GDP share of tertiary sector (-0.84), GDP per capita (0.74), industrial energy intensity (0.46), cement production per capita (0.07), and steel production per capita (0.03).

Regional results show that GDP per capita, cement production per capita, and industrial energy intensity have significantly positively effects on energy consumption per capita, and tertiary sector share has significantly negatively impacts on energy consumption per capita, all at the $10 \%$ level or lower in all three regions. The effects of these factors differ among regions. A $1 \%$ increase in GDP per capita will increase energy consumption per capita in eastern, western, and central China by $0.83 \%$, $0.85 \%$, and $0.51 \%$, respectively. A $1 \%$ increase in the tertiary sector value-added share of total GDP will decrease energy consumption per capita significantly $(1.23 \%)$ in eastern China, which is about two times the effect in the central region $(0.61 \%)$, and almost one and a half times the effect in western China $(0.89 \%)$. The elasticity of industrial electricity intensity on energy consumption per capita is 0.63 in the eastern region, slightly greater than that in central China (0.50), and significantly greater than that in the west (0.41). The elasticity of cement production per capita on energy consumption per capita in is significantly higher in central China (0.16) than that in eastern China (0.05).

Steel production per capita is significantly positively correlated with energy consumption per capita at the $1 \%$ level in the eastern and central regions, but is not statistically significant in the west. The effects of steel production per capita are significantly stronger in the central region (0.14) than in the eastern region (0.01).

\section{Discussion}

We found that across all regions and provinces GDP per capita is significantly positively associated with energy consumption per capita, indicating that increased affluence will increase energy consumption. Our results show that industrial electricity intensity is significantly positively associated with energy consumption per capita. Our results also indicate that a structural change from the secondary to the tertiary industry sector is associated with reduced energy consumption per capita, because energy intensity in the tertiary sector is generally lower than that in the secondary sector. Our empirical analysis also revealed that a reduction in heavy industry production is linked with a decrease in energy consumption per capita, an intuitive result.

We found that the magnitude of the effects from economic transition and technology change on energy consumption per capita of the variables described herein differ among regions. The impact of tertiary sector share on energy consumption per capita decreases from eastern to western and central China. For a given increase in tertiary share, the most significant decrease in energy consumption per capita occurred in eastern China. In our opinion, this finding may be attributable to the difference in the composition of the tertiary sector in each region. In eastern China, wholesale and retail, financial, and real estate account for more production than in western and central China, which have larger proportions of transportation and hotels and catering services. Financial and real estate services are 
generally less energy intensive than are transportation and hotels and catering. Thus, those developing service sectors that require less energy produce larger energy savings from the structural shift to the tertiary sector. This finding underscores the effect of internal structural differences within the service sector itself between three regions, as less energy intensive service subsectors would contribute to less energy consumption than more energy intensive service subsectors.

We used industrial electricity intensity as an indicator of industrial energy efficiency. Our results show that an increase in industrial electricity efficiency would generate the most energy savings in eastern China, slightly more than in central China and significantly more than in the west. We think this result reflects the fact that the more industrially-developed eastern region has more higher-value, or electricity-dominant, types of industries. Thus, in the east, a particular change in industrial electricity intensity would produce the greatest change in total energy use. Meanwhile, industries in the less developed central and western regions rely to a greater extent on primary fuels such as coal, so that a change in industrial electricity intensity would have less impact on total energy use. For future research, we recommend also investigating total industrial energy intensity as an indicator of overall energy efficiency in order to rule out the impacts on energy consumption from the difference in fuel mix within industries.

We used cement and steel production to examine the effect of overcapacity in heavy industries on energy consumption. We found that the effect of steel production on energy consumption is not statistically significant in western China, but is in the east, and even more so in central China. This finding may reflect the fact that industrial technology is more advanced in eastern provinces. Thus, a reduction in heavy industry production will have a more significant effect in central regions where energy intensity currently remains high.

In order to better understand future energy consumption in China and in different regions of China, we used estimation results to forecast energy consumption in China and by region in 2020 and 2030. We developed four scenarios to illustrate different levels of economic growth, structural change, shift of capacity in heavy industries, and efficiency improvement. The baseline scenario is the modest expectation of economic growth and structural change. We developed assumptions for GDP and population in 2020 based on the goals in the national and provincial 13th Five-Year Plan. From 2020 to 2030, we assume national population and GDP follows the trend illustrated by IEA [28] and allocated to each province using the same population or GDP share in 2020. For tertiary sector share, we interpolated it to 2020 based on the real growth rate from 2015 to 2016 and also compared it with the goal in the provincial 13th Five-Year Plan for each province, and then took the larger number of the two for the 2020 assumption. Then, we assumed that from 2020 to 2030, the tertiary sector share for each province grows at half of the annual growth rate from 2015 to 2020. For cement and steel production, we assumed that they grow from 2016 to 2020 at an annual growth rate from 2016 to 2017, and grow from 2021 to 2030 at half of the annual growth rate from 2016 to 2020. For industrial electricity intensity, we assumed a 10\% reduction from 2015 to 2020, as forecasted by IEA [29], and then a $10 \%$ reduction from 2021 to 2030 .

Then, we developed a high economic growth scenario (i.e., high growth scenario) to illustrate a more rapid growth economy. Under this high growth scenario, the annual economic growth rate from 2016 to 2020 was assumed to be $1 \%$ higher than the baseline scenario, and from 2020 to 2030 it was $0.5 \%$ higher. The third scenario (i.e., baseline + fast transition scenario) and the forth scenario (i.e., high growth + fast transition scenario) were based on the baseline scenario and the high economic growth scenario respectively, but assuming aggressive structural change scenario to show a faster transition from industrial sector to service sector, a heavy industry shift scenario to demonstrate a steel capacity shift from the east to the west region, and a technology innovation scenario where industrial electricity intensity further decreases. Specific assumptions for these four scfenarios are descrbied in Table 8. The forecast results show that in 2020, China's total energy consumption is estimated to be about 4.8-4.9 billion tce (3.4-3.5 tce per capita), which will grow to 5.0-5.4 billion tce in 2030 (3.5-3.8 tce per capita) without considering faster structural change and technology innovation, whereas with a 
more aggressive structural shift from the secondary industry to the service sector and energy efficiency gains, total energy consumption in 2020 and 2030 could be $4.4-4.6$ billion tce (3.1-3.2 tce per capita) and 4.3 to 4.6 billion tce (3.0-3.2 tce per capita), respectively. Figure 4 shows the energy consumption in these four scenarios with regional breakdown.

Table 8. Specific assumpsions of key variables under different scenarios.

\begin{tabular}{|c|c|c|c|c|}
\hline & & & Baseline & High Growth \\
\hline \multirow{6}{*}{$\begin{array}{l}\text { GDP average annual growth } \\
\text { rate }(\%)\end{array}$} & \multirow{2}{*}{ East } & $2016-2020$ & 6.71 & 7.71 \\
\hline & & $2021-2030$ & 3.35 & 3.85 \\
\hline & \multirow{2}{*}{ Central } & $2016-2020$ & 6.37 & 7.37 \\
\hline & & $2021-2030$ & 3.18 & 3.68 \\
\hline & \multirow{2}{*}{ West } & $2016-2020$ & 7.39 & 8.39 \\
\hline & & $2021-2030$ & 3.69 & 4.19 \\
\hline & & & Baseline & Fast transition \\
\hline \multirow{6}{*}{ Tertiary share (\%) } & \multirow{2}{*}{ East } & By 2020 & 58 & 60 \\
\hline & & By 2030 & 66 & 69.5 \\
\hline & \multirow{2}{*}{ Central } & By 2020 & 52 & 54 \\
\hline & & By 2030 & 62 & 65 \\
\hline & \multirow{2}{*}{ West } & By 2020 & 54 & 55 \\
\hline & & By 2030 & 62 & 65 \\
\hline \multirow{6}{*}{$\begin{array}{l}\text { Steel production annual } \\
\text { growth rate }(\%)\end{array}$} & \multirow{2}{*}{ East } & 2016-2020 & 2.44 & 1.94 \\
\hline & & $2021-2030$ & 1.22 & 1.22 \\
\hline & \multirow{2}{*}{ Central } & $2016-2020$ & 2.44 & 2.44 \\
\hline & & $2021-2030$ & 1.22 & 1.47 \\
\hline & \multirow{2}{*}{ West } & $2016-2020$ & 2.44 & 2.94 \\
\hline & & $2021-2030$ & 1.22 & 1.72 \\
\hline \multirow{2}{*}{$\begin{array}{c}\text { Industrial electricity intensity } \\
\text { annual change rate }(\%)\end{array}$} & \multirow{2}{*}{ All regions } & $2016-2020$ & -2 & -4 \\
\hline & & $2021-2030$ & -1 & -2 \\
\hline & & & \multicolumn{2}{|c|}{ All scenarios } \\
\hline \multirow{6}{*}{$\begin{array}{l}\text { Population annual growth } \\
\text { rate }(\%)\end{array}$} & East & 2016-2020 & \multicolumn{2}{|c|}{0.44} \\
\hline & & $2021-2030$ & \multicolumn{2}{|r|}{0.1} \\
\hline & Central & $2016-2020$ & \multicolumn{2}{|r|}{1.4} \\
\hline & & 2021-2030 & \multicolumn{2}{|r|}{0.1} \\
\hline & West & $2016-2020$ & \multicolumn{2}{|c|}{0.46} \\
\hline & & $2021-2030$ & \multicolumn{2}{|r|}{0.1} \\
\hline
\end{tabular}



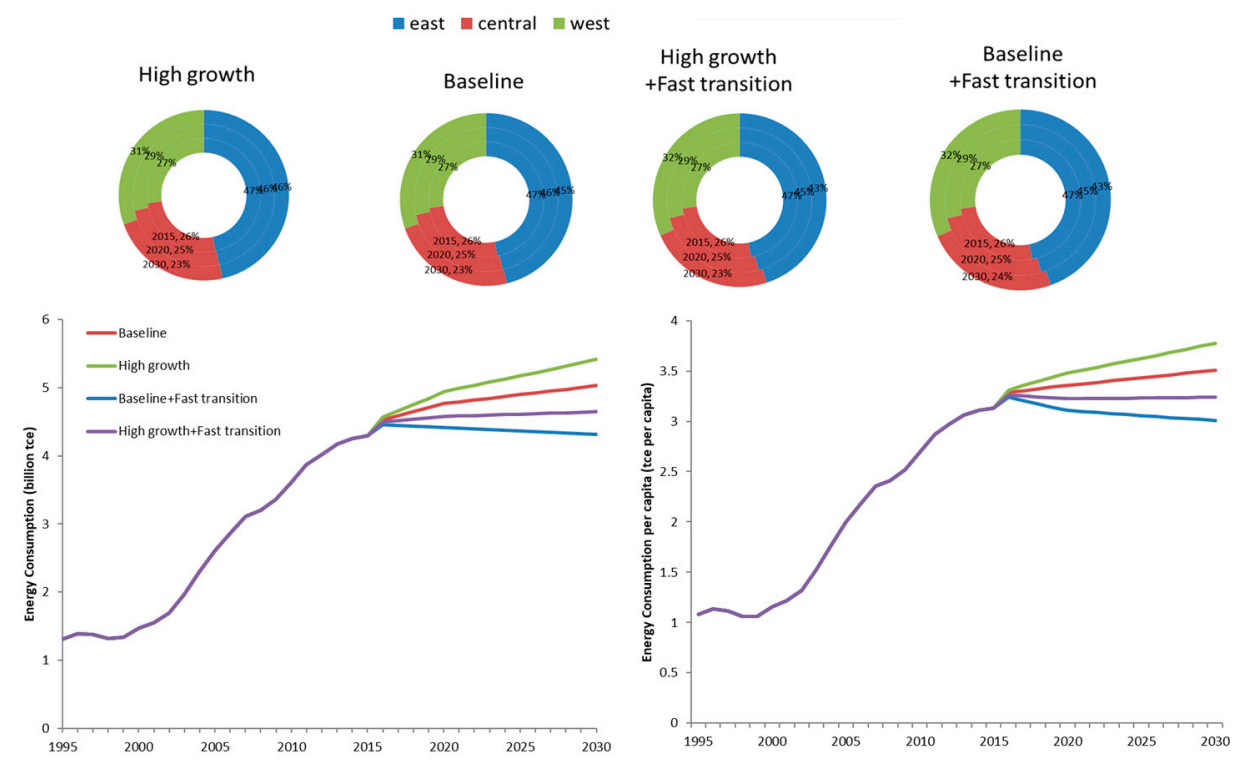

Figure 4. Energy Consumption History (1995-2015) and Forecast (2016-2030) under Four Scenarios with Regional Energy Consumption Share in 2015, 2020, and 2030.

\section{Conclusions}

The research described in this paper used panel data for 30 Chinese provinces from 1995 to 2015 to evaluate the effects of economic transition (i.e., structural shift from the industrial to the tertiary sector and reduction in industrial overcapacity), and improvements in energy efficiency on energy consumption. In addition to analyzing the effects of those mechanisms nationwide, we divided the sample into three geographic and economic regions to evaluate regional differences. Besides these key mechanisms, we also considered the affluence level. We found that, at the national level the structural shift to the tertiary sector, reduction in cement and steel production per capita, and decrease in electricity intensity in the industrial sector all have statistically significantly negative effects on energy consumption per capita.

At the regional level, we found that the GDP share of the tertiary sector shows its greatest impact on reducing energy consumption in the eastern region, because that region contains more service sub-sectors having low energy intensities, such as the financial sector. The western and central regions have more energy-intensive service sub-sectors, such as transportation and hotels and catering. These results highlight the importance of considering the composition of the tertiary sector during a structural shift, because the energy intensity of a service sector may offset the savings from the economic shift from the industries to service sectors.

Reduction in cement and steel production would reduce energy demand more in the central region than in the eastern region, likely because industries are more energy intensive in the central region. Lessening the industrial overcapacity in both regions would significantly lower energy consumption. Improvements in industrial electricity efficiency also help reduce energy consumption, an effect most evident in eastern China, followed by the central and then western regions. Our results show that energy savings from improvements in electricity efficiency are greatest in regions where industry is highly electrified. In general, the economic transition to the tertiary sector and improved energy efficiency can help reduce energy consumption, but integrated analysis and management of structural shifts, electrification, and improved efficiency are vital to achieving the maximum possible energy reduction.

Based on our model, we forecast energy consumption in China will reach 4.8 billion tce in 2020 and further grow to 5.0 billion tce in 2030 under the baseline scenario. A higher projection in economic growth could further increase the energy consumption to 4.9 billion tce in 2020 and 5.4 billion tce in 2030. If economic transition (structural shift to the service sector and heavy industry shift from the 
eastern region to the western region) and technology innovation happens at a more rapid pace, energy consumption could potentially be growing at a much slower rate and plateaus with economic growth at outlined in China's 13th Five-Year Plan.

Author Contributions: Conceptualization, X.L. and J.L.; Data curation, J.C.; Formal analysis, X.L., J.H. and H.L.; Methodology, X.L. and J.H.; Supervision, J.L.; Writing—original draft, X.L. and H.L.; Writing—review \& editing, J.L. and J.H.

Funding: This work was supported by the MJS Foundation under Lawrence Berkeley National Laboratory Contract No. DE-AC02-05CH11231.

Acknowledgments: We thank Cecilia Han Springer for her valuable comments.

Conflicts of Interest: The authors declare no conflict of interest.

\section{References}

1. National Development and Reform Commission. 13th Five-Year Plan of Renewable Energy Development; National Development and Reform Commission: Beijing, China, 2016. Available online: http://www.ndrc. gov.cn/zcfb/zcfbghwb/201612/W020161216661816762488.pdf (accessed on 1 December 2018)(In Chinese).

2. National Bureau of Statistics of China (NBS). 2018 National Data. Available online: http://data.stats.gov.cn (accessed on 1 March 2019)(In Chinese).

3. Zhang, C.; Xu, J. Retesting the causality between energy consumption and GDP in China: Evidence from sectoral and regional analyses using dynamic panel data. Energy Econ. 2012, 34, 1782-1789. [CrossRef]

4. Rathnayaka, R.K.T.; Seneviratna, D.M.K.N.; Long, W. The dynamic relationship between energy consumption and economic growth in China. Energy Sources B Econ. Plan. Policy 2018, 13, 264-268. [CrossRef]

5. Zhang, X.P.; Cheng, X.M. Energy consumption, carbon emissions, and economic growth in China. Ecol. Econ. 2009, 68, 2706-2712. [CrossRef]

6. Yuan, J.H.; Kang, J.G.; Zhao, C.H.; Hu, Z.G. Energy consumption and economic growth: Evidence from China at both aggregated and disaggregated levels. Energy Econ. 2008, 30, 3077-3094. [CrossRef]

7. Wang, D.; Nie, R.; Shi, H.Y. Scenario analysis of China's primary energy demand and $\mathrm{CO}_{2}$ emissions based on IPAT model. Energy Procedia 2011, 5, 365-369. [CrossRef]

8. Song, M.; Wang, S.; Yu, H.; Yang, L.; Wu, J. To reduce energy consumption and to maintain rapid economic growth: Analysis of the condition in china based on expanded IPAT model. Renew. Sustain. Energy Rev. 2011, 15, 5129-5134. [CrossRef]

9. Auffhammer, M.; Wolfram, C.D. Powering up China: Income distributions and residential electricity consumption. Am. Econ. Rev. 2014, 104, 575-580. [CrossRef]

10. Zhang, C.; Zhou, K.; Yang, S.; Shao, Z. On electricity consumption and economic growth in China. Renew. Sustain Energy Rev. 2017, 76, 353-368. [CrossRef]

11. Zhang, Q.; Liao, H.; Hao, Y. Does one path fit all? An empirical study on the relationship between energy consumption and economic development for individual Chinese provinces. Energy 2018, 150, 527-543. [CrossRef]

12. Fang, G.; Tian, L.; Fu, M.; Sun, M.; He, Y.; Lu, L. How to promote the development of energy-saving and emission-reduction with changing economic growth rate-A case study of China. Energy 2018, 143, 732-745. [CrossRef]

13. Zhang, C.; Lin, Y. Panel estimation for urbanization, energy consumption and $\mathrm{CO}_{2}$ emissions: A regional analysis in China. Energy Policy 2012, 49, 488-498. [CrossRef]

14. Hao, Y.; Wang, L.; Zhu, L.; Ye, M. The dynamic relationship between energy consumption, investment and economic growth in China's rural area: New evidence based on provincial panel data. Energy 2018, 154, 374-382. [CrossRef]

15. Yang, Y.; Liu, J.; Zhang, Y. An analysis of the implications of China's urbanization policy for economic growth and energy consumption. J. Clean. Prod. 2017, 161, 1251-1262. [CrossRef]

16. Wang, S.S.; Zhou, D.Q.; Zhou, P.; Wang, Q.W. $\mathrm{CO}_{2}$ emissions, energy consumption and economic growth in China: A panel data analysis. Energy Policy 2011, 39, 4870-4875. [CrossRef]

17. Dietz, T.; Rosa, E.A. Effects of population and affluence on $\mathrm{CO}_{2}$ emissions. Proc. Natl. Acad. Sci. USA 1997, 94, 175-179. [CrossRef] [PubMed] 
18. Shi, A. The impact of population pressure on global carbon dioxide emissions, 1975-1996: Evidence from pooled cross-country data. Ecol. Econ. 2003, 44, 29-42. [CrossRef]

19. Wang, S.; Fang, C.; Guan, X.; Pang, B.; Ma, H. Urbanisation, energy consumption, and carbon dioxide emissions in China: A panel data analysis of China's provinces. Appl. Energy 2014, 136, 738-749. [CrossRef]

20. Lee, C.C. Energy consumption and GDP in developing countries: A cointegrated panel analysis. Energy Econ. 2005, 27, 415-427. [CrossRef]

21. Levin, A.; Lin, C.-F.; Chu, C.-S.J. Unit root tests in panel data: Asymptotic and finite-sample properties. J. Econom. 2002, 108, 1-24. [CrossRef]

22. Im, K.S.; Pesaran, M.H.; Shin, Y. Testing for unit roots in heterogeneous panels. J. Econom. 2003, 115, 53-74. [CrossRef]

23. Maddala, G.S.; Wu, S. A comparative study of unit root tests with panel data and a new simple test. Oxf. Bull. Econ. Stat. 1999, 61, 631-652. [CrossRef]

24. Choi, I. Unit root tests for panel data. J. Int. Money Financ. 2001, 20, 249-272. [CrossRef]

25. Hoechle, D. Robust standard errors for panel regressions with cross-sectional dependence. Stata J. 2007, 7, 281-312. [CrossRef]

26. NBS. China Statistical Yearbooks for years from 1995 to 2015; China Statistics Press: Beijing, China, $1995-2015$.

27. NBS. China Energy Statistical Yearbooks for years from 1995 to 2015; China Statistics Press: Beijing, China, 1995-2015.

28. International Energy Agency. World Energy Outlook 2018; OECD/IEA: Paris, France, 2018.

29. International Energy Agency. World Energy Outlook China Special Report, China Energy Outlook 2017; OECD/IEA: Paris, France, 2017.

(C) 2019 by the authors. Licensee MDPI, Basel, Switzerland. This article is an open access article distributed under the terms and conditions of the Creative Commons Attribution (CC BY) license (http://creativecommons.org/licenses/by/4.0/). 